\title{
Late outcome of right ventricular outflow tract repair using bicuspid pulmonary prosthesis in tetralogy of Fallot surgery repair: case report
}

\author{
Resultado tardio da reconstrução da via de saída do ventrículo direito com prótese pulmonar bicúspide \\ na correção da tetralogia de Fallot: relato de caso
}

\author{
Miguel Angel MALUF ${ }^{1}$
}

RBCCV 44205-1134

\begin{abstract}
Resumo
É apresentado o caso de uma paciente de 19 anos de idade, sexo feminino, portadora de tetralogia de Fallot com anel pulmonar hipoplásico. O diagnóstico foi feito com ecoDopplercardiograma e cateterismo cardíaco. A correção cirúrgica foi realizada com 2 anos de idade. Para a reconstrução da valva pulmonar e via de saída do ventrículo foi utilizada prótese bivalvular pulmonar porcina. A paciente teve boa evolução clínica durante 17 anos. A avaliação pós-operatória demonstrou: discreta insuficiência pulmonar, discreto gradiente transvalvar pulmonar, desempenho do ventrículo direito preservado e prótese pulmonar sem calcificação. Esse é o procedimento adotado pela nossa Instituição para a correção da tetralogia de Fallot, nos últimos 20 anos.
\end{abstract}

Descritores: Tetralogia de Fallot/cirurgia. Cardiopatias congênitas/cirurgia. Resultado de tratamento.

\section{INTRODUCTION}

The results of biventricular surgical repair of congenital heart disease with obstruction of the pulmonary ventricle are satisfactory.

The use of prosthesis with no valves induced the development of valvar pulmonary insufficiency (VPI), is

1. Full Professor; Adjunct Professor.

This study was carried out at Cardiovascular Surgery Discipline of UNIFESP - EPM - São Paulo, SP, Brazil.

\begin{abstract}
We present a case of a 19 year-old female patient, with tetralogy of Fallot and hypoplastic pulmonary ring. Diagnosis was performed by echocardiography and cardiac catheterization. The surgical repair was performed at the age of 2 years old. A right ventricular outflow tract remodeling was performed using a porcine pulmonary bicuspid prosthesis. The patient presented a uneventful follow-up during 17 years. Postoperative assessment has shown: mild pulmonary insufficiency and mild pulmonary ventricle gradient, satisfactory right ventricular performance and prosthesis not presenting calcification. This is an option to correct the tetralogy of Fallot adopted by our Institution in the last two decades.
\end{abstract}

Descriptors: Tetralogy of Fallot/surgery. Heart defects, congenital/surgery. Treatment outcome.

now questioned, indicating the main cause for right ventricular dysfunction [1-3].

Therefore, right ventricle (RV) diastolic function should be carefully monitored in the long-term follow-up of patients undergoing correction of tetralogy of Fallot (TOF) with trans-annular enlargement.

The VPI is known as one of the most important factors

Correspondence address:

Miguel A. Maluf. Av. Ibirapuera 2120, Cj . 144 - Moema - São Paulo, SP, Brasil - CEP: 04028-001.

E-mail: miguelmaluf@gmail.com 
that cause RV dilation due to volume increase and ejection fraction decrease after surgical correction.

Studies on the issue have established the need to repair the PV using valved prosthesis, minimizing or preventing VPI, which is considered the cause for late RV dysfunction [4].

This case report represented a model of our experience started in 1991, at São Paulo Federal University (UNIFESP), on 203 consecutives patients, with RV obstruction submitted to $\mathrm{RV}$ outlet tract (RVOT) remodeling, utilizing a preserved porcine pulmonary prosthesis (bicuspid or trileaflet).

\section{CASE REPORT}

Adult, 19 year-old, female, with tetralogy of Fallot, submitted to surgical correction 17 years ago. Clinical examination shows a functional class I (New York Heart Association) patient that has not taken medication in the last 15 years and presents no restriction to perform physical activities.

\section{Surgical correction}

At the age of 2 years old, she was referred to the Pediatric Cardiology Service at UNIFESP. The clinical examination showed moderated cyanosis, hypoxia and low weigh. Diagnosis of tetralogy of Fallot with hypoplastic pulmonary ring was done by Doppler-echocardiogram and cardiac catheterization.
The operation was performed on February 24, 1992 using cardiopulmonary bypass, moderated hypothermia and cross clamping aorta. For the myocardial protection it was used continued cold blood retroplegia (coronary sinus). The ventricular septal defect (VSD) was closed with bovine pericardium, using right atrium approach and RV approach to remove pulmonary stenosis. To remodel RVOT was used a porcine pulmonary prosthesis, preserved in glutaraldehydeformaldehyde solution. After transection of the pulmonary ring the dysplastic pulmonary valve was preserved and an $11 \mathrm{~mm}$ bicuspid pulmonary prosthesis was adjusted to pulmonary ring and enlarging the pulmonary infundibulum. The aortic cross clamping time was $76 \mathrm{~min}$. and the cardiopulmonary bypass time was $100 \mathrm{~min}$.

\section{Late follow-up}

On March 2009, the patient underwent clinical examination and image evaluation. During the cardiac inspection it was detected on the pulmonary focus: systolic $++/ 4+$ and diastolic $+/ 4+$ murmur.

Table 1. Cardiac catheterization (pressure in $\mathrm{mmHg}$ )

\begin{tabular}{lccc}
\hline & S & D1 & D2 \\
\hline RV & 40 & 0 & 11 \\
PA & 33 & 9 & - \\
LV & 155 & 0 & 12 \\
Ao & 155 & 80 & - \\
\hline
\end{tabular}

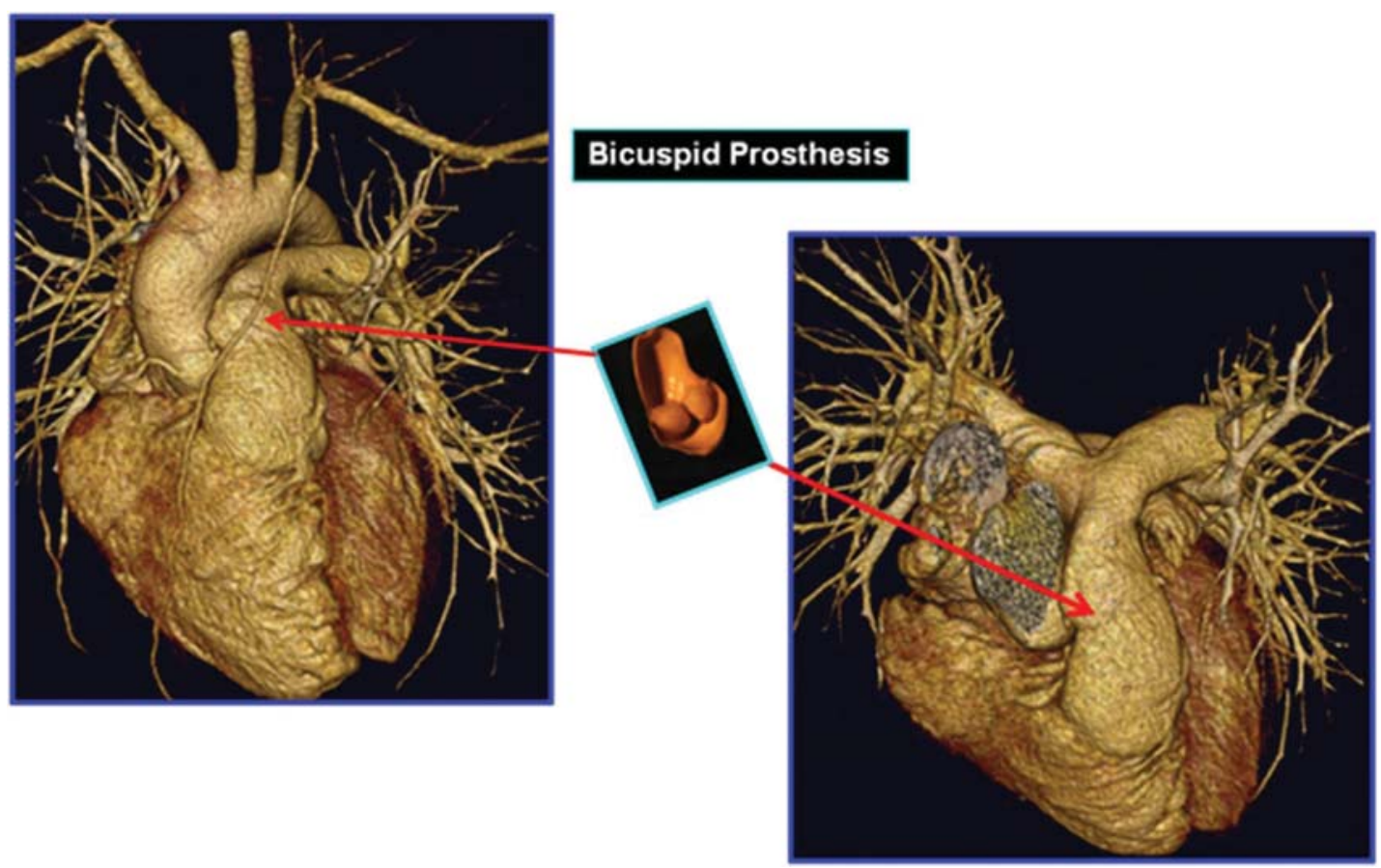

Fig. 1 - Computerized tomography in a patient with tetralogy of Fallot submitted to surgical remodeling of the right ventricle outlet tract with an implant of a preserved porcine pulmonary bicuspid prosthesis (in detail). (M-I, HBP: Febr. 2009) 


\section{Bicuspid Prosthesis}

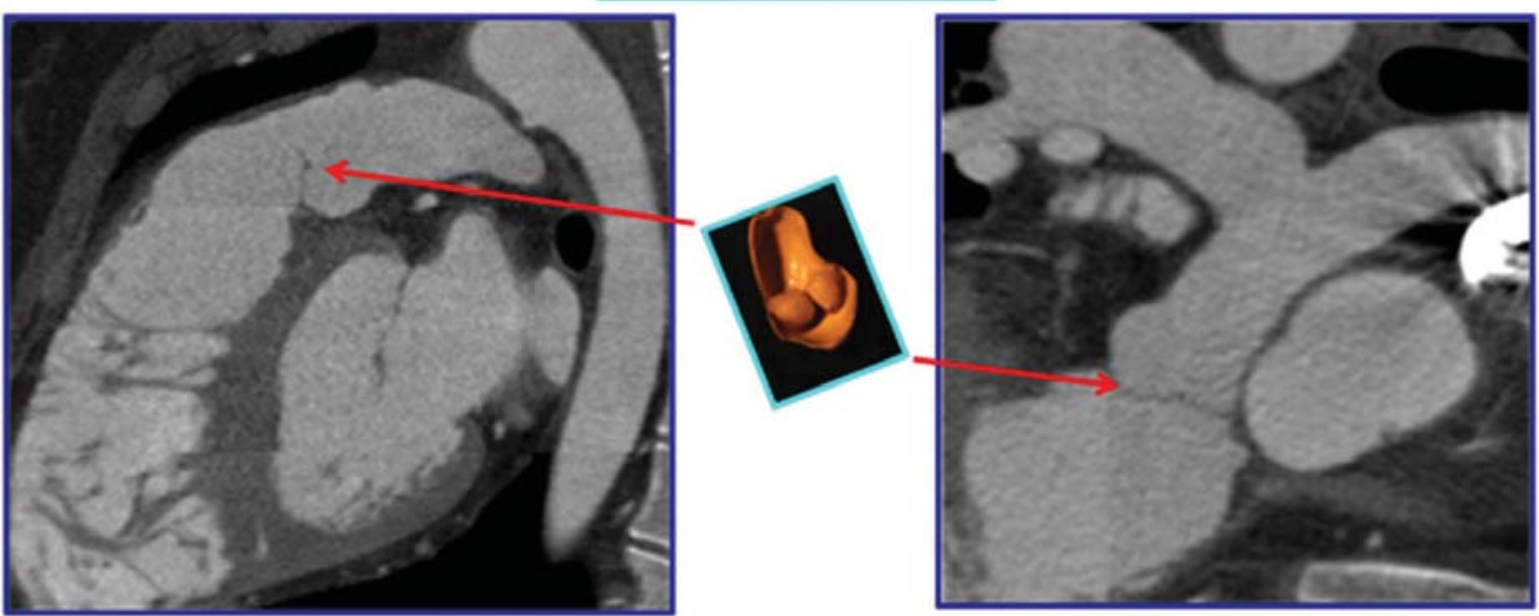

Fig. 2 - Computerized tomography in a patient with tetralogy of Fallot submitted to surgical remodeling of the right ventricle outlet tract with an implant of a preserved porcine pulmonary bicuspid prosthesis (in detail). (M-I, HBP: Febr. 2009)

The image examination showed: Thoracic Rx: normal cardiothoracic index; ECG: Sinus rhythm and incomplete right bundle block; Doppler- echocardiogram: RV-PA gradient $=30 \mathrm{mmHg}$; mild PVI; mild tricuspid insufficiency and preserved RV/ left ventricle (LV) function.

The findings of the cardiac catheterization study are shown in the Table 1.

Normal pressure in the right chambers; Gradient RV$\mathrm{PA}=7 \mathrm{mmHg}$; Absent $\mathrm{LV}$ to RV residual shunt.

The Figures 1 and 2 show some details of the computerized tomography performed in the late follow-up.

\section{DISCUSSION}

The valved prosthesis of choice in RVOT reconstruction provides a challenge for cardiac surgeons. English language articles on valved prosthesis for RVOT reconstruction were retrieved from the MEDLINE database regarding the commonly used homografts, stented xenografts and stentless xenografts, and the occasionally used autologous tissue valved prosthesis as well. The conclusion of this study shows: The prosthesis failure and explants are inevitable. This phenomenon is worse during the late follow-up. The mechanisms involved in prosthesis failure are unknown, even though they were accounted for calcification and extensive intimal proliferation, and somatic outgrowth.

Due to the limited availability of homografts, different alternatives are used for the replacement of the pulmonary valve. When comparing the porcine pulmonary xenograft with the pulmonary homograft, we can observe that xenograft stenosis were mainly located at the distal anastomosis, while the leaflets were preserved. Nevertheless, the Homografts showed valve stenosis and wall calcification.

Since 1991 our Institution has been using a preserved porcine pulmonary prosthesis: bicuspid prosthesis in patients under 2 years-old and pulmonary prosthesis (trileaflet) in children, in order to reconstruct the pulmonary valve and RVOT in patients with TOF, inducing a decrease in the residual VPI [5]. This series of patients undergoing TOF repair surgery have had an excellent prognosis and a good rate of survival in about $80 \%$ of the cases, seventeen years after the surgery and $78 \%$ of the surviving patients are free of reoperation and show good physical ability during exercise and practicing sports, in the late follow-up.

A biologically engineered xenogenic heart valve based on the concept of acellularization offers promising results as a mean of overcoming the limitations of current prosthetic valves. These experimental studies suggest that: acellularized xenogenic porcine valved conduits are biocompatible heart valve prostheses that are repopulated with autologous cells and extracellular matrices over a reasonable lifespan and preserve the functional integrity without degeneration or calcification of the leaflet.

Cryopreserved and decellularized pulmonary homograft valves are submitted to an experimental model in order to study and detect the incidence of calcification in functional chronic implants [6]. Actually, the experimental results obtained might be predictive of the prolonged durability and functionality of a cryopreserved - decellularizedglycerolized allograft valve. 


\section{CONCLUSION}

1. Right ventricular remodeling consists of a safe and standardized technique.

2. The early reconstruction of the pulmonary valve and right ventricle outlet tract could maintain the right ventricular performance for a long period.

3. The prosthesis function must be analyzed during the follow-up.

4. Nevertheless, the porcine pulmonary prosthesis has shown satisfactory results on the long term.

\section{REFERENCES}

1. Bricker JT. Sudden death and tetralogy of Fallot. Risks, markers, and causes. Circulation. 1995;92(2):158-9.

2. Owen AR, Gatzoulis AM. Tetralogy of Fallot: late outcome after repair and surgical implications. Semin Thorac Cardiovasc Surg Pediatr Card Surg Annu. 2000;3:216-26.

3. Nollert G, Fischlein T, Bouterwek S, Böhmer C, Klinner W, Reichart B. Long-term survival in patients with repair of tetralogy of Fallot 36-year follow-up of 490 survivors of the first year after surgical repair. J Am Coll Cardiol. 1997;30(5):1374-83.

4. Yuan SM, Mishaly D, Shinfeld A, Raanani E. Right ventricular outflow tract reconstruction: valved conduit of choice and clinical outcomes. J Cardiovasc Med (Hagerstown). 2008;9(4):327-37.

5. Maluf MA, Braile DM, Silva C, Catani R, Carvalho AC, Buffolo E. Reconstruction of the pulmonary valve and outflow tract with bicuspid prosthesis in tetralogy of Fallot. Ann Thorac Surg. 2000;70(6):1911-7.

6. Hopkins RA, Jones AL, Wolfinbarger L, Moore MA, Bert AA, Lofland GK. Decellularization reduces calcification while improving both durability and 1-year functional results of pulmonary homograft valves in juvenile sheep. J Thorac Cardiovasc Surg. 2009;137(4):907-13. 